\title{
Lumen
}

Selected Proceedings from the Canadian Society for Eighteenth-Century Studies

\section{'Des sentiments si nôtres': Stylisation and Dramatisation in the Bucoliques of André Chénier}

\section{R. Gamble}

Volume 21, 2002

URI : https://id.erudit.org/iderudit/1012271ar

DOI : https://doi.org/10.7202/1012271ar

Aller au sommaire du numéro

Éditeur(s)

Canadian Society for Eighteenth-Century Studies / Société canadienne d'étude du dix-huitième siècle

ISSN

1209-3696 (imprimé)

1927-8284 (numérique)

Découvrir la revue

Citer cet article

Gamble, D. R. (2002). 'Des sentiments si nôtres': Stylisation and Dramatisation in the Bucoliques of André Chénier. Lumen, 21, 131-142.

https://doi.org/10.7202/1012271ar

Copyright (C Canadian Society for Eighteenth-Century Studies / Sociéte canadienne d'étude du dix-huitième siècle, 2002
Ce document est protégé par la loi sur le droit d'auteur. L'utilisation des services d'Érudit (y compris la reproduction) est assujettie à sa politique d'utilisation que vous pouvez consulter en ligne.

https://apropos.erudit.org/fr/usagers/politique-dutilisation/ 


\section{7. 'Des sentiments si nôtres': Stylisation and Dramatisation in the Bucoliques of André Chénier}

Dedicated to the memory of Eugène Joliat, 1911-1999, Professor of French and Comparative Literature at University College in the University of Toronto.

In the memorable preface he prepared for his own edition of the $\mathrm{Bu}$ coliques, the French poet José-Maria de Hérédia wrote that the creative genius of André Chénier revealed three distinct parts; he was at once a poet of his century, of his time, and of all time:

Les Élégies, les Poèmes, l'Hermès sont l'œuvre du plus grand des poètes du XVIII ${ }^{\mathrm{e}}$ siècle; les Hymnes, les Odes, les Iambes, du seul grand poète de la Révolution; et les Bucoliques d'un grand poète de tous les âges. Il semble qu'il les ait écrites ... sub specie aeternitatis (Hérédia, 162-63).

This preface dates from 1905, but critical attention and the place they have found in anthologies since that time appear to confirm Hérédia's suggestion that of all the verse the Bucoliques would hold the most lasting appeal. What I would like to do in the pages that follow is briefly to explain why this should be so by assessing the importance of two particular aspects of Chénier's pastoral poetry: the broad descriptions it contains of people and places chosen from classical antiquity, and the intimate situations in which these characters are regularly portrayed. Through a consideration of Chénier's views on the art of poetry and the practice of his contemporaries, I hope to show that there is no contradiction between these two elements, and that their curious juxtaposition is in large measure responsible for the impact that these poems, at their best, are still capable of making.

Although the Bucoliques often bear as titles the names of their central characters (Néaere, Hylas, la jeune Tarentine, Mnazile et Chloé), these poems are concerned less with the continuing story of any single 
character than with the culminating point of a specific situation in which he is found already placed: the central figure is regularly viewed as part of a larger tableau, or quadro (Italian for picture), to use the two words Chénier himself preferred to refer to his verse. As these terms suggest, the poems are eminently visual, so much so that Chénier's inspiration for them can at times be ascribed to painting, or sculpture ${ }^{1}$; and the verb peindre in his work is often synonymous with the composition of poetry: describing ' $l$ 'auteur qui demeure éternellement' (683), Chénier wrote: 'Il voit tout, il sent tout, il peint tout ... depuis la cèdre jusqu'à l'hysope' (684). Elsewhere in the same essay he lauds the example of 'les sublimes peintures d'Homère, de Virgile, de Racine, du Tasse' (651). Chénier has been described, rightly, as a sensualist (Scarfe, 169), but in his verse he gave pride of place, like his century (Launay, 151), to the faculty of sight.

Given his emphasis on visual representation, it is worthwhile to consider Chénier's manner of description, and his use of adjectives in particular. Those habitually chosen to portray the main characters in these poems are commonplace, and noteworthy only for their restraint. The beauty of la jeune Tarentine is suggested by a single reference to 'son beau corps' (12), that of la jeune Locrienne by a phrase describing her companion, 'aussi beau qu'elle est belle' (13). Central personae in other poems are introduced as 'le beau Mnazile' (15), or '[le] jeune et bel Hylas' (28). As even these few examples suggest, together with doux, the adjectives jeune and beau recur in the Bucoliques again and again. Of course other attributes can be found, but when they are used less sparingly, especially in the longer poems such as 'Le Malade' and 'L'Aveugle,' it is usually to establish a contrast between two characters or their situations: between le malade and la belle Daphné, for instance, or l'aveugle (Homer) and the three young shepherds who find him by the sea.

Reference to colour is made through these adjectives, but pace SainteBeuve, who praised Chénier for his application of 'un procédé de couleur' (qtd. in Picon, 889), in the great majority of these poems there is

1 See, for instance, G. Walter's notes in the Pléiade version of Chénier's complete works, currently the most widely-held edition and to which all textual references in this study are made: 843 (I:2); 844 (III:3); 853 (XX:1), etc. Occasionally it is Chénier himself who emphasises these sources, as in fragment IV of the 'Sujets et ébauches de bucoliques': 'Il faut peindre des jeunes filles marchant vers la statue d'un Dieu, tenant d'une main sur leur tête une corbeille de fleurs et de l'autre des pans de leur robe ... et d'autres attitudes qu'il faut tirer des marbres, des pierres et des peintures antiques' (530). 
little beyond a few preferred primary shades, black and white especially. ${ }^{2}$ Mention of 'blonds cheveux,' which is very positive in Chénier, is not infrequent; but what colours there are can be used to convey less a literal than a figurative sense, as in his references to 'le fruit encore vert' ('Arcas et Bacchylis,' 14),'les noirs ennemis, les deux oiseaux de proie' (XVII, 24), or even '[la] blanche et douce colombe' (XVII, 24).

Ordinary and to modern readers almost monochromatic, the adjectives Chénier used to describe the characters in these poems are none the less evocative in their imprecision and lack of detail; Chénier suggests emotional as well as physical states and prefers, by shorthand, to describe the effect rather than its cause, impression to expression. Dazzling outlines are suggested, but rarely detailed: what Chénier accomplishes with surprising economy is the stylisation, in fact, the idealisation of his characters. This is the description of Hylas and the water nymphs who bear him away:

Reines au sein d'un bois d'une source prochaine,

Trois Naïades l'ont vu s'avancer dans la plaine.

Elles ont vu ce front de jeunesse éclatant,

Cette bouche, ces yeux. Et leur onde à l'instant

Plus limpide, plus belle, un plus léger zéphyre,

Un murmure plus doux l'avertit et soupire.

Il accourt (28).

This idealisation is facilitated by the identity of the characters Chénier chose to write about. While on occasion he undertook such familiar episodes as the return of Ulysses or the death of Hercules, it is clear by their relative infrequency that Chénier generally preferred to avoid such well-known personae in favour of very minor figures (like Hylas) whose myths complemented his own vision, or completely imaginary characters (such as Néaere or Dryas) whom he could portray entirely as he wished. In this way most of them could be idealised without fear of contradiction; they could also be presented as complements to the natural world of these tableaux, which is no less captivating and in no sense less stylised.

Classical historians have observed that the real recovery of the world of antiquity began only with the eighteenth century (Pedley, 19). The

2 For an illuminating study of Chénier's use of colour as a neo-classicist between the Classicism of Racine and the Romanticism of Musset, see the article by Richard Sayce listed below. 
excavations at Herculaneum and Pompeii, the engravings of Piranesi, and the treatises of Winckelmann fuelled contemporary interest in the material existence of Greece and Rome, about which more was soon known than ever before. Chénier was an avid classicist, and this increased knowledge is reflected in his inclusion in the Bucoliques of objects in everyday use in ancient times: 'un vase d'argile' in 'Hylas' (28) or 'une coupe d'onyx' in 'Le Malade' $(30,33)$, for instance, not to mention the many items listed in the banquet scene of 'Le Mendiant' (35-37):

Sur ses mains, de l'aiguière d'argent,
Par une jeune esclave une eau pure est versée.
Une table de cèdre où l'éponge est passée,
S'approche, et vient offrir à son avide main
Et les fumantes chairs sur les disques d'airain,
Et l'amphore vineuse et la coupe aux deux anses (37).

It should not be assumed, however, from this careful application of local colour that the settings in the Bucoliques are much more detailed than the portrayal of the characters themselves. The natural world is of course everywhere present in these pastoral poems, in the 'Fleurs, bois mélodieux, vallons, grottes sauvages' ('Néaere,' 11); and the elements frequently responsible for the development of the action are highlighted: 'le vent impétueux' which sweeps la jeune Tarentine into the sea (12), for instance, 'l'onde pure' whose naiads seduce Hylas (29), or 'la noire tempête' which spares only Dryas (30). But as these examples demonstrate, the adjectives used to depict the various landscapes of ancient Greece are usually as general and conventional as those chosen to describe the central personae. When indeed adjectives are included at all: often particulars of the landscape are simply enumerated, with minimal qualification. The stylisation of nature in these Bucoliques is in fact so pronounced that critics have found it difficult to distinguish the setting of one poem from that of another:

Les paysages des Bucoliques? On serait tenté de dire qu'il n'y en a qu'un ou qu'il n'y en a pas. Même ceux de ses élégies ... se fondent dans une sorte de lieu idéal ... Pour l'inventer et le peindre, il ne s'est aucunement soucié d'originalité. Le paysage qu'il aime est l'habituel paysage de l'idylle, ... celui de la tradition poétique française ... (Fabre, Chénier 201).

In the Bucoliques places and people alike are stylised to perfection. They may be described in muted shades, but they are invested with a suave and consummate beauty akin to the faultless lines of a vase by Josiah Wedgewood (1730-1795), or a drawing by John Flaxman (17551826), both contemporaries of Chénier and inspired, as he was, by the neo-classical revival. This idealisation of man in nature is a defining 
characteristic of Chénier's bucolic vision, and essential to its creation. So pronounced was this cult of the beautiful that it may be considered a primary tenet of his poetics: a requisite quality in any young artist, Chénier claimed, must be his sensitivity to beauty:

Mais toi, jeune élève, si les chefs-d'œuvre antiques, chaque jour contemplés ... enflamment ton courage et laissent dans ton cœar un long aiguillon d'émulation et de gloire; si l'idée ou la vue de la beauté allume tes sens et te met hors de toi; ... viens, viens, travaille; c'est toi qui feras des chefs-d'œuvre (651),

he wrote in his Essai sur les causes et les effets de la perfection et de la décadence des lettres et des arts.

A famous American philosopher once concluded that 'imaginary forms ... differ in dignity and beauty not according to their closeness to fact or type in nature, but according to the ease with which the normal imagination reproduces the synthesis they contain' (Santayana, 112). While nothing could be rarer - or more agreeable ${ }^{3}$ - than the ideal beauty which informs the Bucoliques, little, paradoxically, could be more ordinary than the adjectives Chénier used to portray it: but for that reason alone the impact of these adjectives is more immediate, and all the more striking; and because they are so deliberately vague, so deftly suggestive, they are wholly inclusive: each reader has the lattitude to interpret, as he pleases, Chénier's broad descriptions and to imagine for himself these characters in their settings.

It is noteworthy that Chénier's treatment of description in these poems is reflected in his choice of the themes they are meant to illustrate: childhood and youth, passion, love and friendship, death. Like their classical antecedents they are in fact very general, dwelling on moments and emotions foreign to no one, emphasising always the very brief span allotted for their enjoyment. Chénier was well aware that his concentration on these universal themes would establish a point of contact with his readers, that the basic emotions they evoked would draw them into his poems:

Quel lecteur peut quitter un livre où il se retrouve partout, un livre qu'il semble avoir fait lui-même, où il dit à chaque page: J'ai éprouvé cela ... J'avais pensé cela

3 As G. Santayana has convincingly argued, 'beauty is an ultimate good, something that gives satisfaction to a natural function, to some fundamental need or capacity of our minds. Beauty is therefore a positive value that is intrinsic, it is a pleasure ... It is pleasure objectified' (32-33). 
mille fois ... Il y a des sentiments si purs, si simples, des pensées si éternelles, si humaines, si nôtres, si profondément innées dans l'âme que tous les lecteurs les reconnaissent à l'instant (683-684).

Beyond the accessibility of their idealised portraits, however, and the universality of their themes - in itself a kind of stylisation - the continuing attraction of Chénier's Bucoliques may be found in the particular manner in which they are presented to the reader: and that manner, so distinct from the 'flat narrative style' of his contemporaries (Scarfe, 162), is dramatic. The tableaux or quadri from which these poems proceed are very theatrical in their focus and development; they are usually centred around one character who, at the moment of depiction, embodies a single, intense feeling: Ulysses is understood to represent wrath, Néaere fidelity, le mendiant misery, Naïs (from 'L'Oaristys') innocence, and so on.

Like Racine's plays, Chénier's Bucoliques, however brief, generally begin in medias res. In the interesting preface he wrote for his edition of the Bucoliques in 1943, Julien Luchaire observed that: 'Comme les artistes anciens, Chénier excelle à composer par tableaux équilibrés, à saisir le mouvement à l'instant où il se cristallise en attitudes successives' (Chénier/Luchaire, 7). Through the poem the outcome of this action is then disclosed: la jeune Locrienne loses her audience (13), and Naiis, charmingly, her innocence (16-22); but normally the action at the heart of these tableaux is more dramatic: Ulysses is revenged (26-27), or Hylas abducted (28-29); a young bride is drowned ('La Jeune Tarentine,' 11-12) or a young soldier slain ('Xanthus,' 27-28); Dryas is spared by the sea (29-30), or a great poet - Homer - is revered and revealed ('L'Aveugle,' 42-48). The tension arising from these events, morever, is rarely interrupted, for the tableaux create a framework into which Chénier as narrator never intrudes; any utterance in the first person 'is always that of a character, whether legendary or created by him' (Scarfe, 193). This dramatic objectivity leads to a restraint on Chénier's part in the $\mathrm{Bu}$ coliques perfectly suited to their timeless themes; and this in turn brings these poems, at their most successful, close to the aesthetic model of their time, to 'eine edle Einfalt und eine stille Größe' as first formulated by Winckelmann in 1755 (Winckelmann, 20).

4 For stylistic reasons which are related but distinct, A.-M. Taisne arrived at a similar conclusion in her article listed below (23). Winckelmann's famous phrase may be rendered in English as 'a noble simplicity and tranquil grandeur.' 
To heighten the illusion of life and render the sequence of events in these poems more vivid, Chénier regularly uses the present tense. Here are the most dramatic lines from what may be his most famous bucolique:

Le vent impétueux qui soufflait dans les voiles

L'enveloppe. Étonnée, et loin des matelots,

Elle crie, elle tombe, elle est au sein des flots.

Elle est au sein des flots, la jeune Tarentine (12).

For the same reason Chénier occasionally abandons narration enlivened by quotations from his characters for an openly dramatic dialogue form, as in 'L'Oaristys' (16-22) - Greek for friendly conversation - 'Mnazile et Chlóe' (15-16), or 'Arcas et Bacchylis' (14-15). Much could be added about the skill with which these brief dramas are developed, about their psychological realism, convincing dialogue, humour and wit, all of which bring their stylised pastoral figures to life; but more apposite to the present discussion is the way in which these dialogues - like the characters' apostrophes in other bucoliques - enhance Chénier's summary references to the traditional decor of the idyll: these are the first lines, spoken by Chloé, of 'Mnazile et Chloé':

Fleurs, bocage sonore, et mobiles roseaux

Où murmure Zéphire au murmure des eaux,

Parlez, le beau Mnazile est-il sous vos ombrages? (15)

These lines resonate not only because of the evocative power of the few select references to the setting, but also because, as so often in these Bucoliques, the natural world has been included as an active participant in the unfolding drama: as in the drowning of la jeune Tarentine (11-12), for instance, the abduction of Hylas by water nymphs (28-29), or even the death of Néaere: 'Mon âme vagabonde à travers le feuillage/Frémira' (11). These natural settings are lent further dimension, as we have seen, when their presence is revealed not by an impersonal narrator, but through the eyes of the characters themselves (Chloé and Néaere in the examples just given).

Or through their ears: as in the theatre, the two primary senses in the Bucoliques are sight and sound; allusions to what is heard in Chénier's pastoral world are often included as well. Among others, there are references to 'bois mélodieux' ('Néaere,' 11), 'des loups les tristes hurlements' ('Le Mendiant,' 40), 'du rossignol la voix pure et légère' and ' 1 'onde mugissante' (both in 'L'Aveugle,' 44); there is also mention of the many voices of man, from '[la] voix noble et touchante' of Homer ('L'Aveugle,' 43) to '[la] voix toujours tendre et doucement plaintive' of 
Néaere (11). It is the dramatic context of the Bucoliques which breathes life not only into their idealised personae but also the conventional descriptions of the natural world around them. Hérédia, who understood this, was right to conclude in his early preface that 'Chénier renouvelle dans la poésie française le sentiment de la nature que seul $\mathrm{La}$ Fontaine n'avait pas entièrement méconnu' (Hérédia, 163).

Nor is it difficult, however briefly, to demonstrate how Chénier's accomplished style further contributes to the fundamentally dramatic structure of these poems. The contrast of elements and perspectives they contain regularly serves to sharpen their outlines: in 'Le Malade,' for example, the worries of a disconsolate mother at the sickbed of her only son are vividly presented, and all the more convincing when set against her fond memories of his childhood (31); but this viewpoint presently shifts, so that her state of mind is sharply contrasted with his own: while her son is no happier, his tender recollections are of quite another order:

Ô visage divin! ô fêtes! ô chansons!

Que je la vois encor, cette vierge dansante! (32)

The tension between youthful naivety and amorous guile underpins, as we have seen, the episode describing the seduction of Hylas by water nymphs, but this antinomy also lies at the heart of Bucolique XVI, as the contrasts of even the first lines make clear:

Ô jeune adolescent, tu rougis devant moi.

Vois mes traits sans couleur; ils pâlissent pour toi.

C'est ton front virginal, ta grâce, ta décence.

Viens. Il est d'autres jeux que les jeux de l'enfance (22).

Many other Bucoliques display this dual perspective so characteristic of drama: in 'L'Aveugle,' for instance, the curiosity and inexperience of the respectful young shepherds stand in counterpoint to the candour and wisdom of the venerable old bard whom they befriend; in 'Le Mendiant,' similarly, the vision of the beautiful young daughter of Lycus is immediately set against the 'hideux aspect' (34) of her father's former patron, now destitute; and in 'La Liberté' the starkly contrasting political views of the protagonists, further emphasised in this poem by the dialogue form, are revealed through distinct appearances and attitudes which pique the interest of the reader from the outset.

Such interest is often fuelled by the rhythm of these poems: Chénier's frequent accumulation of brief verbs can infuse even a single line with dramatic urgency. A noteworthy example is found in the citation above 
from 'La Jeune Tarentine' ('Elle crie, elle tombe, elle est au sein des flots,' 12) where two verbs of motion, the second following hard upon the first, lead to a third describing her final position. Verbal alchemy animates many other lines as well; it can bring to life the struggle of shipwrecked Dryas with the waves:

Il dit; plonge; et perdant au sein de la tourmente

La planche sous ses pieds fugitive et flottante,

Nage, et lutte ... (30);

the consternation of a young woman frantically rousing her lover:

Fuis, ne me livre point. Pars avant son retour;

Tiens, regarde, adieu, pars, ne vois-tu pas le jour?

('La Jeune Locrienne,' 12);

or the terrible death of Antinous, slain by Ulysses' arrow:

Sa tête se renverse et l'entraîne et succombe.

La coupe de sa main fuit. Il expire. Il tombe.

Sa bouche, tous ses traits en longs et noirs torrents

Jaillissent (26).

The last two lines of this passage also demonstrate how an impression of dramatic movement can be prolonged from one line to the next through an imaginative use of enjambement. It has been argued that Chénier's treatment of the classical alexandrine had little about it that was new, ${ }^{5}$ but his deft manipulation of the possibilities it offered clearly underlie many of his most striking lines. ${ }^{6}$

The commonplace nature of the adjectives found in the Bucoliques has already been discussed, but they broadly reflect the familiar character of most of the words used in these poems: 'le fonds de son vocabulaire,'

5 See Jean Fabre, Chénier, 172-176; but see also Francis Scarfe, André Chénier, 173-174.

6 In 'André Chénier et le mythe de la régénération' Jean Starobinski has noted the importance of Chénier's particular metrical style for the flow and expressiveness of his verse: 'La prosodie de Chénier, en usant largement de licences poétiques, cherche à exploiter toutes les ressources de souplesse, de flexibilité, de "facilité" de la langue française; elle évite les coupes rigides, les rythmes trop réguliers, qui eussent emprisonné un sujet "à l'antique" dans une structure figée" (590). 
Jean Fabre has observed, 'restera constitué par des mots d'une vertu éprouvée: humains, mortels, trépas, nocher, pasteur, arène, etc., parfois relevés d'une teinte d'archaïsme ...' (Fabre, 162). Such a straightforward poetic vocabulary, immediately comprehensible, in no way impedes the power and immediacy of lines expressing dramatic movement. But nor does his syntax, which is also noteworthy in this regard: while almost all the devices of classical rhetoric find a place in his poetry, including extended Virgilian similes (as in the first lines of 'Néaere,' 10), the development of Chénier's most convincing verse remains essentially uncluttered. In her analysis of 'La Jeune Tarentine' A.-M. Taisne has emphasised that the syntax is ' $\mathrm{d}$ 'une rigoureuse simplicité' (Taisne, 22).

The use of dramatic irony, finally, informs the organisation of two of the longest Bucoliques, 'Le Mendiant' and 'L'Aveugle.' In each instance, this device is carefully elaborated and fully integrated into the development of the poem to hold the reader's attention as long as possible. In 'Le Mendiant' the mysterious beggar at the feast is described throughout as 'l'étranger'; and although subtle clues point to him as the earlier benefactor of the host, it is not confirmed before the last division of the poem. In 'L'Aveugle' the identity of the old blind poet the three young shepherds come upon is questioned repeatedly from the beginning: 'Quel est ce vieillard blanc, aveugle et sans appui?' (42); but in spite of unmistakable hints here as well, it is only after the enchantment of his song has been evoked that he is revealed as Homer with the last word of what some critics consider to be Chénier's greatest poem (Scarfe, 164).

All these elements of his style contribute to the 'tableau[x] pleins[s] de chaleur et de mouvement' (828) that Chénier so praised in the work of other authors and attempted to emulate in his own. ${ }^{7}$ The drama underlying these tableaux had of course a specific purpose: to involve the reader, through his interest and emotions, as deeply in the poem as possible. It has been observed that Chénier considered it more appropriate for the poet to inspire than to be inspired, and that it was particularly

7 Other means by which Chénier breathed life into his faultless vision of a distant classical past have been suggested by Jean Starobinski in his discussion of a fragment entitled 'Une Leçon de flûte': 'Suffit-il de relever ... les traits stylistiques qui exercent un effet compensatoire de rapprochement: rôle des participes présents, animation par le détail et par le mouvement réitéré (... recommençaient vingt fois)? Il y a davantage encore à percevoir. Il faut mentionner une catégorie d'images, plus ou moins explicitées, dont le dénominateur commun est du domaine tactile: images d'effleurement et de contact, où corps et objets se touchent ... Le tableau a beau appartenir au cadre antique, il est chargé de valeurs sensibles, qui suscitent l'émoi et le plaisir présents' (105). 
the emotional impact of the Ancients that he wanted to restore to verse (Scarfe, 98). To accomplish this, Chénier attempted to express the irresistible vision of ideal beauty that for him lay at the source of the creative act:

Laisse là ces rides, ces sillons, ces plis de la peau, vestiges profondes des maladies et de la décrépitude, avant-coureuses de la mort. Fais-moi un corps qui n'ait éprouvé, qui ne craigne nul changement, nul outrage des années (651),

he exhorted the aspiring artist; and then he elaborated the dramatic context to animate his vision and engage the emotions of his readers as deeply as possible, so that in the end '[les âmes de tous les lecteurs] se réunissent à celle de l'auteur, elles semblent se reconnaître toutes et se souvenir qu'elles ont une origine commune' (684). This evocation of a common humanity was for Chénier the ultimate objective of every artist $^{8}$; in the Bucoliques he achieved this essential communication through the use of stylisation and dramatisation, elements in his hands uniquely complementary and so artfully combined that modern readers, like the Romantics who discovered him, are able still not merely to imagine, but to experience the subdued pathos of his 'rêveries profondes' (Fabre, 'La poésie,' 102).

\section{D.R. GAMBLE}

Memorial University

\section{Works Cited}

Chénier, André. Bucoliques (Pièces principales). Ed. Julien Luchaire. Collection Les chefsd'œuvre. Paris: Sorlot, 1943.

.CEuvres complètes. Ed. Gérard Walter. Bibliothèque de la Pléiade. Paris: Gallimard, 1966.

Fabre, Jean. Chénier. Connaissance des lettres. Paris: Hatier, 1966.

.'La poésie et les poètes selon André Chénier.' L'Information littéraire 18 (1966): 99105.

8 Elsewhere in the same long discourse (Essai sur les causes et les effets de la perfection et de la décadence des lettres et des arts), Chénier declared: 'Homo sum: voilà le principe, le but, l'objet de tous les arts ...' (680). 
Hérédia, José-Maria de. 'Le manuscrit des Bucoliques.' La Revue des deux mondes $30\left(1^{\mathrm{er}}\right.$ novembre 1905): 146-167.

Launay, Michel and Georges Mailhos. Introduction à la vie littéraire du XVIII siècle. Collection Études. Paris: Bordas, 1984.

Pedley, John Griffiths. Greek Art and Archaeology. $2^{\text {nd }}$ ed. Upper Saddle River, New Jersey: Prentice-Hall, 1998.

Picon, Gaëtan. 'La fin du dix-huitème siècle: André Chénier.' Histoire des littératures. Ed. Raymond Queneau. Vol. III. Bibliothèque de la Pléiade. Paris: Gallimard, 1958. 887-893.

Santayana, George. The Sense of Beauty: Being the Outline of Aesthetic Theory. 1896. New York: Dover, 1955.

Sayce, R.A. '"La blanche Oloossone": Some Reflections on Romanticism and Classicism.' In Balzac and the Nineteenth Century: Studies in French Literature Presented to H.J. Hunt. Ed. D.G. Charlton, J. Gaudon, A.R. Pugh. Leicester: Leicester University Press, 1972. 283-295.

Scarfe, Francis. André Chénier: His Life and Work. Oxford: Clarendon Press, 1965.

Starobinski, Jean. 'Une Leçon de flûte.' Langue française 6 (23 septembre 1974): 99-107. .'André Chénier et le mythe de la régénération.' Savoir, faire, espérer. Vol. 2. Bruxelles: Facultés universitaires Saint-Louis, 1976. 577-591.

Taisne, A.-M. 'Chénier et l'antiquité: influences poétiques et artistiques.' Revue de l'Institut de formation et de recherches en littérature 4 (1979): 5-24.

Winckelmann, Johann Joachim. Gedanken über die Nachahmung der griechischen Werke in der Malerei und Bildhauerkunst. Sendschreiben. Erläuterung. $2^{\text {nd }}$ ed. 1756. Ed. Ludwig Uhlig. Stuttgart: Reclam, 1982. 